\title{
O CONSUMO E A CONFIGURAÇÃO DO GÊNERO NA INFÂNCIA
}

\author{
The consumption and the configuration of gender in the childhood \\ El consumo y la configuración de género en la infancia
}

Juliana Petermann

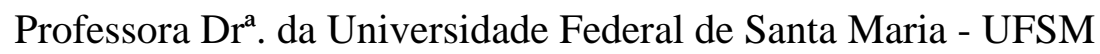

petermann@ufsm.com.br

Desireè Ribas Fumagalli

Mestra em Comunicação pela Universidade Federal de Santa Maria

desireeribas@gmail.com

\section{Resumo}

Neste texto objetiva-se analisar a configuração das concepções de gênero na infância pelo viés do consumo e de outros processos de socialização, com auxílio da psicologia do desenvolvimento. Para tanto, este artigo estrutura-se nos eixos: consumo, gênero e infância. Como principal condução metodológica, assumiu-se a cartografia, cujo pressuposto é o direcionamento da atenção da pesquisadora ou pesquisador. Pelo viés cartográfico, selecionamos duas técnicas de coletas de dados, a observação participante e a entrevista. Como resultado principal, destacamos a atuação efetiva do consumo na configuração das concepções de gênero, principalmente através dos significados incutidos nos brinquedos e na apropriação coletiva desses, que segue uma lógica atrelada aos estereótipos sexuais.

Palavras-chave: Consumo. Gênero. Infância.

\begin{abstract}
Our objective is to analyze the configuration of gender concepts in the childhood through consumption and the other socialization processes, with the aid of developmental psychology. Therefore, this article is structured in three axes: consumption, gender and childhood. The main methodological approach is the cartography, whose assumption is to direct the attention of the researcher. By the cartographic perspective, we selected two techniques of data collection, participant observation and interviews. As a central result, we highlight the activeness of consumption in the configuration of gender concepts, mainly through the meanings instilled in toys and their collective appropriation, following a logic linked to sexual stereotypes.
\end{abstract}

Key words: Consumption. Gender. Childhood.

\section{Resumen}

Nuestro objetivo es analizar la configuración de las concepciones de género en la infancia, a través del consumo y de los otros procesos de socialización, con la ayuda de la psicología del 
desarrollo. Para eso, este artículo está estructurado en los ejes, consumo, género e infancia. El enfoque metodológico principal es la cartografía, lo que implica dirigir la atención del investigador. Por el sesgo cartográfico, se seleccionaron dos técnicas de recolección de datos, observación participante y entrevistas. Uno de los resultados centrales es el rendimiento del consumo en la configuración de las concepciones de género, principalmente a través de los significados inculcados en los juguetes y en la apropiación general de estos, siguiendo una lógica ligada a estereotipos sexuales.

Palabras clave: Consumo. Género. Infancia.

\section{INTRODUÇÃO}

A mídia, juntamente com a família, a escola e demais referências simbólicas e culturais cumpre um importante papel no processo de desenvolvimento infantil. O intuito neste estudo é considerar esse papel perante as questões de gênero. Portanto, esta pesquisa tem a intenção de analisar a configuração das concepções de gênero na infância, a partir do consumo e de outros processos de socialização.

Pautamos o gênero para além do caráter biológico, mas por meio de um viés social e relacional, ou seja, entendemos as relações de gênero inseridas no contexto sociocultural, e como partes constituintes da identidade dos sujeitos e sujeitas.

Consumo e gênero serão analisados neste estudo a partir do entrelaçamento com a infância, desse modo, ao abordar principalmente as concepções de crianças, levamos em consideração uma etapa de formação não só do papel social, mas da personalidade do indivíduo como um todo. A formação da opinião na infância é estruturada no processo de socialização, isto é, nas relações estabelecidas com as pessoas e ambientes a sua volta. Podemos entender que a família, a escola, a mídia e o contexto cultural contribuem com a formação dos sujeitos de forma muito significativa.

Elencamos como problema norteador desse estudo: Como se dá a atuação do consumo aliado a outros processos de socialização na configuração das concepções de gênero na infância? Assim, objetivamos compreender o papel do consumo na configuração das concepções de crianças, em específico, as concepções de gênero. Como o consumo, seja ele material ou midiático, é um dos fatores que compõe o processo de socialização, será considerado aliado a esses processos ligados ao universo infantil.

Para auxiliar na busca da resposta ao problema de pesquisa, traçamos como objetivo: analisar a configuração das concepções de gênero na infância pelo viés do consumo e de outros processos de socialização, com auxílio da psicologia do desenvolvimento. Por fim, 
para atingir o objetivo de pesquisa, nos apoiamos na cartografia, como predisposição metodológica.

\section{MÉTODO}

De acordo com Kastrup (2007), o método cartográfico se estrutura por meio das variedades do funcionamento atencional que direcionam o trabalho do pesquisador ou pesquisadora e consiste em um método voltado para o estudo da subjetividade. Portanto, a cartografia é uma forma de estruturar e delinear o trabalho de pesquisa por meio do direcionamento da atenção em uma atividade exploratória. "Tais explorações mobilizam a memória e a imaginação, o passado e o futuro numa mistura difícil de discernir. Todos esses aspectos caracterizam o funcionamento da atenção do cartógrafo durante a produção dos dados numa pesquisa de campo" (KASTRUP, 2007, p. 18).

Para Kastrup (2007) a condução da atenção é um processo fundamental para a investigação cartográfica e resulta de quatro variantes: o rastreio, o toque, o pouso e o reconhecimento atento. Cada etapa desempenha uma função na exploração do campo e do objeto de estudo.

De acordo com Kastrup (2007) e Deleuze e Guattari (1995) a perspectiva cartográfica implica identificar e construir o objeto de pesquisa de modo complexo, reconhecendo o caráter processual. Para tanto, a autora e os autores adotam o desprendimento de hierarquias e dicotomias como pontos de partida, para que seja possível compreender o objeto em uma perspectiva rizomática, a qual será explorada a seguir.

Nesta pesquisa, o primeiro passo na condução da atenção, denominado rastreio, configurou-se na construção rizomática do objeto. O momento em que as ideias começaram a constituir forma e o estudo começou a se materializar.

Um rizoma é feito de platôs. Gregory Bateson serve-se da palavra "platô" para designar algo muito especial: uma região contínua de intensidades, vibrando sobre ela mesma, e que se desenvolve evitando toda orientação sobre um ponto culminante ou em direção a uma finalidade exterior. (DELEUZE; GUATTARI, 1995, não paginado)

Deleuze e Guattari (1995, não paginado) definem os platôs como "toda multiplicidade conectável com outras hastes subterrâneas superficiais de maneira a formar e estender um rizoma”. Além disso, os autores exploram algumas características que nos auxiliam na 
compreensão do rizoma, como o fato de que qualquer ponto de uma construção rizomática pode e deve ser conectado a qualquer outro, diferente de uma árvore ou raiz que fixam um ponto, uma ordem. Uma estrutura rizomática pode ser rompida, mas não é desestruturada, pois outras linhas retomam a formação. E, ainda, "um rizoma não pode ser justificado por nenhum modelo estrutural ou gerativo. Ele é estranho a qualquer idéia de eixo genético ou de estrutura profunda" (DELEUZE; GUATTARI, 1995, não paginado).

A partir dos pressupostos de Deleuze e Guattari (1995) chegamos a proposta de construção rizomática de nosso objeto de estudo (Figura 1). Essa construção se deu ao adotarmos como ponto de partida a articulação dos três eixos ou platôs centrais - o gênero, a infância e o consumo - para, posteriormente, realizar um movimento exploratório, um rastreio de conceitos e categorias relacionadas com estes eixos. O resultado é uma compilação de categorias que consideramos passíveis de maior aprofundamento tanto teórico como empírico, levando em consideração a complexidade do objeto.

Figura 1 - Construção rizomática do objeto.

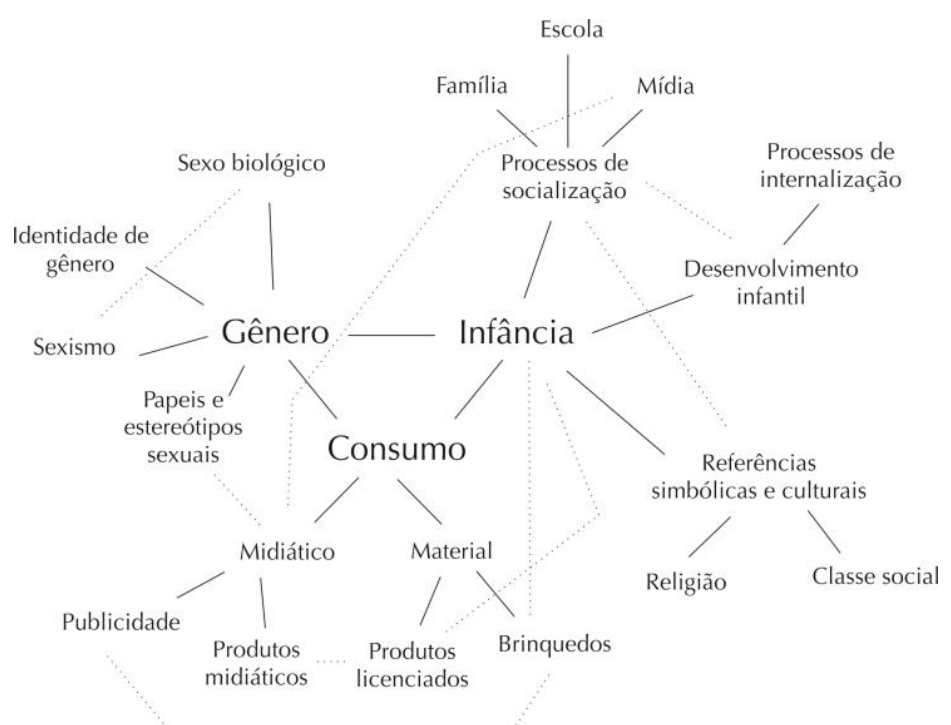

Fonte: Elaborado pela autora a partir dos conceitos Deleuze e Guattari (1995).

As demais etapas da investigação cartográfica (toque, pouso e reconhecimento atento) foram se estruturando conforme os passos da pesquisa. $\mathrm{O}$ toque correspondeu à construção dos pressupostos teóricos. O pouso se estabeleceu na coleta de dados, e, por fim, o reconhecimento atento na análise e construção dos resultados. Esses passos serão explicitados a seguir. 


\subsection{Coleta de dados}

O processo de coleta de dados contou com duas técnicas de pesquisa: a observação participante e a entrevista. Esses procedimentos atuaram no mapeamento do consumo e das concepções de gênero das crianças.

A pesquisa participante, de acordo com Peruzzo (2009) diz respeito à inserção da pesquisadora ou do pesquisador no ambiente natural do fenômeno a ser estudado. Essa inserção propõe uma lógica em que a pessoa investigadora observa o contexto de dentro, compartilhando e vivenciando as atividades e o cotidiano do grupo estudado. Cabe ressaltar que o pesquisador ou pesquisadora mesmo estando inserido ou inserida no contexto, é uma pessoa externa ao grupo, assim sendo, "nunca será idêntico aos observados" (PERUZZO, 2009, p. 127).

Já no que se refere à entrevista, de acordo com Duarte (2009, p. 62) consiste em uma "técnica qualitativa que explora um assunto a partir da busca de informações, percepções e experiências de informantes para analisá-las de forma estruturada.” Assim como a observação participante, a entrevista está mais direcionada à interpretação e cruzamento de informações, do que à definição de conclusões definitivas, sendo uma técnica que propõe certa flexibilidade desde que respeite alguns pressupostos, como um roteiro semi-estruturado, o qual foi empregado nesta pesquisa.

A definição da amostra ocorreu de forma não-probabilística, integrando critérios de intencionalidade e conveniência, considerando especialmente a escola como âmbito de pesquisa, a qual desempenha um importante papel no processo de socialização. A amostra foi então constituída de uma turma de segundo ano com 20 crianças de sete e oito anos de idade.

O período de coleta de dados ocorreu durante quatro semanas em uma escola estadual de Santa Maria (RS), cujo nome será preservado para respeitar o anonimato das crianças e professoras. Nesse período, as três primeiras semanas foram destinadas à observação participante e a quarta semana destinada às entrevistas.

Por meio da observação participante buscamos atentar para pressupostos ideológicos relativos ao consumo, a fim de concretizar uma coleta de dados com clareza suficiente para aplicação da segunda técnica de pesquisa: a entrevista. Durante o período de observação participante foram realizadas atividades planejadas previamente com base no referencial teórico de pesquisa. 
As atividades referentes ao consumo buscaram mapear as principais racionalidades que o envolvem e os principais produtos midiáticos consumidos pelas crianças. Já as atividades referentes ao gênero buscaram mapear traços de divisão entre os sexos e a existência de papéis e estereótipos sexuais.

A partir da observação participante ocorreu a seleção de crianças para as entrevistas. Foram priorizados os relatos mais diversificados e passíveis de maiores aprofundamentos em relação ao consumo e ao gênero.

As entrevistas foram conduzidas no próprio ambiente escolar, de forma individual, tendo como base um roteiro semi-estruturado, contendo cerca de 40 perguntas. Foram selecionadas quatro crianças, dois meninos e duas meninas.

Cabe destacar que todos os procedimentos éticos foram tomados no sentido de respeitar a cessão de direitos de depoimento oral, bem como o compromisso de não identificação de cada depoente. Portanto, ao expor falas das crianças provenientes tanto da observação participante quanto das entrevistas serão utilizados nomes fictícios: Larissa (7 anos), Milena (7 anos), Murilo (8 anos) e Martim (7 anos).

\section{PRESSUPOSTOS TEÓRICOS}

No que se refere aos pressupostos teóricos de pesquisa, o consumo foi abordado por meio da relação com a cultura, considerando as esferas midiática e material. Consideramos este conceito para além da apropriação e do uso dos produtos, mas perante suas múltiplas significações na vida das pessoas, com base em Néstor García Canclini (1995) e Jésus MartínBarbero (1997).

O gênero foi elucidado através de Joan Scott (1989), Pierre Bourdieu (2012) e Guacira Lopes Louro (2008), a fim de compreender suas implicações sociais com auxílio de conceitos como identidade de gênero e estereótipos sexuais.

A infância foi pautada principalmente a partir da psicologia do desenvolvimento proposta por Lev Vygotsky (1991), cuja teoria aborda os processos de desenvolvimento levando em consideração as trocas com o meio. Ainda, a partir de Berger e Luckmann (2011) foram considerados os processos de socialização presentes na infância, como a família, a escola, e demais referências ligadas ao desenvolvimento infantil.

\subsection{Consumo}


Entendemos a mídia, e, em particular o consumo midiático como um processo de socialização. Kellner (2001, p. 82) conceitua a cultura da mídia como uma cultura de "representações que ajudam a constituir a visão de mundo do indivíduo, o senso de identidade e sexo, consumando estilos e modos de vida, bem como pensamentos e ações sociopolíticas”.

O consumo é aqui entendido, a partir de García Canclini (1995), como um processo de afirmação da cidadania e consequentemente, de afirmação da individualidade. A perspectiva de García Canclini (1995) aponta a noção de consumo como um processo de socialização presente no desenvolvimento do indivíduo, e, cabe aqui considerar, especialmente da criança por meio de sua atuação na consolidação da cidadania.

Aprofundando a definição proposta pelo autor, torna-se necessário apontar cinco características ou funções desempenhadas pelo consumo que auxiliarão na construção desse estudo. Tais características serão convertidas posteriormente em categorias de análise. Uma delas configura-se como a racionalidade econômica, o ato de consumo atrelado ao financeiro, ao valor de uso e de troca dos produtos. Outra diz respeito à racionalidade sócio-política interativa e as demandas de consumo relacionadas às disputas entre classes. Já a racionalidade estética e simbólica aborda o consumo com função de distinção, enquanto que a racionalidade integrativa e comunicativa percebe o consumo como elemento socializador e integrador de classes. E, além destas, existe uma quinta característica do consumo, considerada pósmoderna, a racionalidade ritual, que se apresenta através da satisfação de desejos justificados nos significados sociais e no coletivo, a compra exacerbada de presentes no natal é um exemplo. (GARCÍA CANCLINI, 1995).

Esses aspectos do consumo salientados por García Canclini (1995) evidenciam o quanto o conceito é mediado por diversos fatores. Destacamos que o ponto de vista do autor não é restrito ao consumo material, mas propõe uma abordagem cultural do consumo.

Martín-Barbero (1997), em sua teoria, discorre acerca do uso social dos meios. O autor pensa o consumo e a comunicação por meio de diferentes modos de apropriação cultural, como um espaço de reflexão. Apoiamo-nos no autor para compreender melhor este âmbito em que o sujeito receptor está inserido, levando em consideração a cultura.

Martín-Barbero (1997) compreende a importância da natureza comunicativa da cultura. "Isto é, seu caráter de processo produtor de significações e não de mera circulação de informações, no qual o receptor, portanto, não é um simples decodificador daquilo que o emissor depositou na mensagem, mas também um produtor." (MARTÍN-BARBERO, 1997, p. 287). 
A partir da proposta de Martín-Barbero (1997) e de Ronsini (2010) abordamos aqui, três tipos de mediações: a sociabilidade, a ritualidade e a tecnicidade. Ressaltamos que, ao reportar as mediações entendemos que elas transformam os modos de percepção da experiência social, atuando como instâncias que permeiam o espaço existente entre a emissão e recepção, influenciando a percepção final da mensagem (MARTÍN-BARBERO, 1997).

A sociabilidade diz respeito à apropriação cotidiana da existência, "concerne às relações sociais, ao indivíduo/sujeito e seus múltiplos pertencimentos identitários com base em referentes individuais, de gênero, etnia e geração que são estruturados a partir de uma posição de classe" (RONSINI, 2010, p. 13). A ritualidade trata da repetição e operacionalidade na busca do sentido, "se refere aos diferentes usos sociais dos meios e aos diferentes trajetos de leitura” (RONSINI, 2010, p. 9). A tecnicidade é a dimensão constitutiva da comunicação, que transforma as práticas sociais em novas formas de sociabilidade, “remete à construção de novas práticas através das diferentes linguagens midiáticas [...]. Além disso, a tecnicidade aponta para os modos como a tecnologia vai moldar a cultura e as práticas sociais" (RONSINI, 2010, p. 9). Esses três processos de mediação compõem o contexto de recepção da mensagem e serão considerados no que diz respeito ao consumo midiático realizado pelas crianças.

Portanto, o consumo midiático é entendido neste estudo a partir de sua intervenção no modo como as pessoas enxergam o mundo, especialmente, no modo como as crianças nxergam o gênero. O âmbito infantil é considerado público-alvo de diferentes segmentos de mercado, e, nesta pesquisa, abarcaremos os brinquedos e os produtos licenciados, por serem respectivamente, interventores no desenvolvimento infantil e ligados à mídia.

\section{2 Gênero}

Ao abordarmos a noção de gênero temos em vista uma crescente e atual preocupação com o campo, que, a partir dos últimos anos vem se tornando não somente alvo de novos estudos, mas também uma pauta no agendamento midiático e na sociedade em geral.

Para Scott (1989, p. 23) o gênero permeia e influencia as relações, sendo "um meio de decodificar o sentido e de compreender as relações complexas entre diversas formas de interação humana".

Louro (2008), assim como Scott (1989), compreende o gênero para além do determinismo biológico, mas como algo construído socialmente. No entanto, ressalta que "o gênero se constitui com ou sobre corpos sexuados, [assim,] não é negada a biologia, mas 
enfatizada, deliberadamente, a construção social e histórica produzida sobre as características biológicas" (LOURO, 2008, p. 22).

Assim como as autoras, Bourdieu (2012) aponta a existência de uma diferença socialmente construída entre os gêneros e, como possível justificativa para tal construção está a diferença biológica entre os sexos.

O autor entende que "a definição social dos órgãos sexuais, longe de ser um simples registro de propriedades naturais, diretamente expostas a percepção, é produto de uma construção efetuada à custa de uma série de escolhas orientadas" (BOURDIEU, 2012, p. 23). Em síntese, Bourdieu (2012) enfatiza não só o gênero, mas a diferença biológica entre os sexos como uma construção arbitrária naturalizada pela sociedade devido a criações de oposição homóloga.

Louro (2008) destaca a pretensão de compreender o gênero como constituinte da identidade dos sujeitos. Entendemos por identidade de gênero, a identificação do indivíduo social, cultural e historicamente como femininos ou masculinos. "Ao afirmar que o gênero institui a identidade do sujeito [...] pretende-se referir, portanto, a algo que transcende o mero desempenho de papéis, a idéia é perceber o gênero fazendo parte do sujeito, constituindo-o" (LOURO, 2008, p. 25).

Os estereótipos sexuais são construções decorrentes dos papéis sexuais, que interferem na forma como o gênero é compreendido socialmente. Esses estereótipos são edificados desde a infância e alimentados por modelos sociais ligados ao sexo imputado no nascimento e ao contexto cultural. Os papéis e estereótipos são "padrões ou regras arbitrárias que uma sociedade estabelece para seus membros e que definem seus comportamentos, suas roupas, seus modos de se relacionar ou de se portar" (LOURO, 2008, p. 24). Portanto, objetivamos compreender a visão das crianças acerca dessas construções e do papel do gênero em seu contexto social.

\section{3 Infância}

As crianças nascem e de imediato entram em contato com um mundo de signos. Aos poucos, a aprendizagem e o desenvolvimento permitem que elas realizem a apropriação desses signos. Entendendo a importância da língua no desenvolvimento humano, Vygostsky (1991) aponta a "fala" ou a "atividade simbólica" como organizadora de funções psicológicas superiores, como o "pensamento" ou "raciocínio prático". 
A internalização está imbricada em todo o processo de desenvolvimento, já que, Vygotsky (1991) compreende o desenvolvimento de fora para dentro. "Chamamos de internalização a reconstrução interna de uma operação externa” (VYGOTSKY, 1991, p. 63). Essa interiorização de formas de comportamento social e historicamente construídas e enraizadas envolve uma reconstrução da atividade psicológica e compõe o aspecto característico da psicologia humana (VYGOTSKY, 1991).

A partir do entendimento do desenvolvimento pela internalização podemos entender a importância da aprendizagem, pois na concepção do autor é a aprendizagem que leva ao desenvolvimento, sendo que ambos "estão inter-relacionados desde o primeiro dia de vida da criança" (VYGOTSKY, 1991, p. 95).

De acordo com Berger e Luckmann (2011) é por meio da identificação (ligada a fatores emocionais) com outros sujeitos da sociedade, que a criança começa seu processo de interiorização cuja finalidade é o encontro da subjetividade. A interiorização explicitada por Berger e Luckmann (2011) segue pressupostos semelhantes aos do processo de internalização exposto por Vygotsky (1991). “A interiorização só se realiza quando há identificação. A criança absorve os papéis e as atitudes dos outros significativos, isto é, interioriza-os, tornando-os seus" (BERGER; LUCKMANN, 2011, p. 170).

Ao mencionar o processo de socialização estamos nos referindo à predisposição do indivíduo para a sociabilidade e para tornar-se membro da sociedade através de suas relações sociais (BERGER; LUCKMANN, 2011). A socialização está diretamente ligada ao processo de internalização ou interiorização, considerados por Vygotsky (1991) e Berger e Luckmann (2011). A partir dos autores, consideramos aqui três principais instâncias socializadoras: a família, a escola e a mídia.

De acordo com Setton (2002) e Berger e Luckmann (2011) um aspecto importante para a compreensão do papel da família na socialização é o entendimento de que os valores familiares são inicialmente tomados como absolutos e, portanto, são os mais inabaláveis em todo o processo de socialização. Para Bourdieu é “a família que cabe o papel principal na reprodução da dominação e da visão masculinas; é na família que se impõe a experiência precoce da divisão sexual do trabalho e da representação legítima dessa divisão" (2012, p. 103).

Já a apropriação do saber transmitido pela escola varia de acordo com as experiências de vida de cada pessoa, já que, a forma como a criança se relaciona e interioriza conhecimentos depende das pessoas com as quais ela convive (SETTON, 2002). 
Louro (2008, p. 58) aponta a escola como delimitadora de espaços "servindo-se de símbolos e códigos, ela afirma o que cada um pode (ou não pode) fazer, ela separa e institui. Informa o 'lugar' dos pequenos e dos grandes, dos meninos e das meninas”. Esse caráter delimitador reforça uma divisão a partir de estereótipos sexuais, privando e condenando comportamentos que não são socialmente aceitáveis para cada sexo.

De modo geral, compreendemos que, na relação entre consumo, gênero e infância encontramos uma gama de possíveis analogias e tensionamentos. Acreditamos na importância de problematizar, a partir da infância, a compreensão de como se moldam as concepções de gênero desses indivíduos em desenvolvimento.

$\mathrm{Na}$ relação entre mídia e gênero é possível encontrar estereótipos sexuais, o que destaca a importância no tensionamento dessas áreas do conhecimento, principalmente a partir da infância, para compreender como o papel midiático implica na estruturação das concepções de crianças acerca das relações de gênero. Entendendo o papel do consumo perante essa configuração, buscamos compor uma visão ampla a fim de pensar perspectivas para uma prática comunicacional mais ética que atenda e represente a diversidade em todas as suas nuances.

\section{RESULTADOS}

Começaremos a explanação dos resultados obtidos com esta pesquisa propondo um esquema que possibilita uma macro visão das conclusões obtidas com a análise de cada eixo (Figura 2).

Por meio da imagem (Figura 2) podemos observar de forma bastante sintetizada todo o caminho percorrido neste estudo. A partir deste momento, faremos alguns apontamentos que nos permitirão ressaltar as relações estabelecidas entre o consumo, o gênero e a infância ao propor o cruzamento das conclusões obtidas com cada platô pesquisado.

Figura 2 - Macro visão das conclusões obtidas com a análise. 


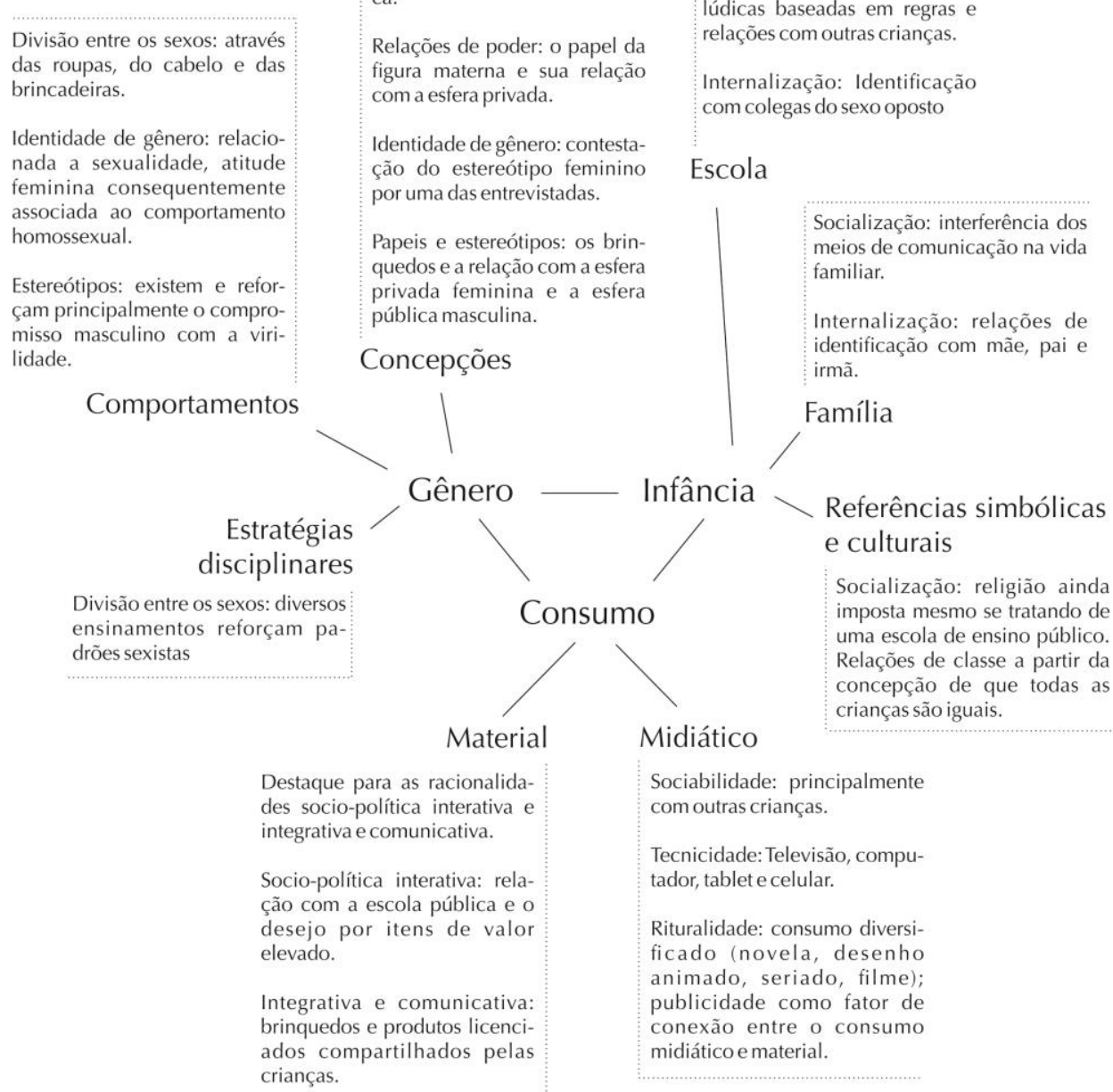

Fonte: Elaborado pela autora.

A partir do consumo material foi possível destacar a relação das crianças principalmente com a racionalidade sócio-política interativa através das relações de classes, e com a racionalidade integrativa e comunicativa por meio do consumo compartilhado. Essas duas racionalidades do consumo se destacaram ao longo da análise. De modo geral, o consumo material é bastante ligado à presença dos pais e das mães, principalmente no que diz respeito ao consumo ritual e ao econômico. No que tange ao consumo midiático, também foi possível observar relações de integração entre as crianças e uma predisposição para o consumo de diferentes produtos midiáticos. Ainda cabe considerar a relação existente entre o consumo midiático e o material através da publicidade e dos produtos midiáticos que se transformam em produtos licenciados, fortemente presentes em roupas, mochilas, calçados e diversos itens utilizados pelas crianças. 
A relação entre consumo e gênero se deu especialmente através desses dois caminhos, por meio do consumo material através dos brinquedos e por meio do consumo midiático através dos produtos midiáticos. No que diz respeito ao consumo material, identificamos a relação entre consumo e gênero com maior detalhamento por meio do papel desempenhado pelo consumo principalmente como forma de integração. Consideramos o brinquedo como um objeto que integra gostos e preferências, e, portanto, um fator que se insere no processo de socialização das crianças. Ao mesmo tempo, os brinquedos consumidos pelas crianças direcionam para a divisão entre os sexos e para uma visão estereotipada que segue padrões de comportamento femininos e masculinos.

Através dessa relação é possível concluir que esses padrões de comportamento se constroem e se afirmam com base em um movimento cíclico, a partir da opinião coletiva. $\mathrm{O}$ próprio estereótipo se torna um fator de definição da racionalidade integrativa e comunicativa, assim como o inverso é verdadeiro. O compartilhamento do consumo reforça os estereótipos, assim como esses reforçam o consumo entre as crianças, principalmente no que diz respeito aos brinquedos, mas também aos produtos licenciados.

No que diz respeito ao consumo midiático foi possível observar uma forte divisão com conteúdos mais consumidos pelas meninas e conteúdos mais consumidos pelos meninos, embora haja uma mescla em alguns pontos. $\mathrm{O}$ encontro entre consumo midiático e consumo material se mostrou um aspecto bastante presente entre as crianças, através de diversos produtos direcionados pelos conteúdos midiáticos e pela publicidade. Dentre os aspectos elencados a partir dos meios de comunicação, o que se mostrou bastante surpreendente e significativo foi a forte presença dos meios e das Tecnologias da Informação e Comunicação (TIC's) no espaço familiar e um consequente enfraquecimento da socialização primária. As relações de socialização se mostraram com muito mais força no espaço escolar, pontualmente através das relações de identificação, o que nos direciona ao próximo apontamento.

Podemos entender que tanto a partir do consumo, quanto a partir do ambiente escolar as relações de socialização entre as crianças desempenham um papel primordial para a construção de suas concepções. É possível considerar o processo de internalização a partir das relações de socialização entre as crianças; do consumo dos meios de comunicação; dos brinquedos e dos produtos licenciados; e por fim, das relações familiares.

No que diz respeito especificamente às concepções e aos comportamentos das crianças relativos ao gênero, podemos destacar alguns aspectos. Como previamente mencionado, a divisão entre os sexos ainda se mostra intensa e reforçada através de práticas cotidianas como 
os brinquedos, as roupas e o corte de cabelo determinados para meninas e para meninos. Identificamos que as estratégias disciplinares oferecidas pela escola cumprem um papel bastante forte em afirmar ainda mais esse padrão. Cabe considerar que os estereótipos não regem o comportamento de todas as crianças e existem visões mais plurais, no entanto, as visões estereotipadas se mostraram mais rígidas, principalmente no que diz respeito ao comportamento masculino. O compromisso dos meninos com a virilidade surgiu em diversos momentos ao longo de nossa discussão e evidenciou a existência de uma visão androcêntrica como aponta Bourdieu (2012). Um dos pressupostos dessa visão androcêntrica é a determinação da esfera pública ao masculino e a esfera privada ao feminino. Esse aspecto foi apontado ao ressaltar as relações de poder no que diz respeito à figura materna e também quando apontamos o brincar de boneca em contraponto com o brincar de dirigir no direcionamento dos estereótipos. Além dos pressupostos da visão androcêntrica, temos também as consequências que se mostraram no momento em que ocorreu a relação entre gênero e sexualidade. Houve, por parte dos meninos, a intolerância de que meninos demonstrassem comportamentos femininos. Os comportamentos considerados por eles como femininos foram consequentemente entendidos como comportamentos homossexuais. Destacamos esse ponto como um dos mais inquietantes e reducionistas ao longo de todo o contato com as crianças.

Essas constatações acerca do gênero moldam um panorama bastante restrito e pouco determinista, de acordo com a proposição deste trabalho, que de maneira alguma propunha uma constatação geral ou reducionista, mas sim uma primeira aproximação com este entrelaçamento entre consumo, gênero e infância. Acreditamos que uma das constatações que podemos absorver é que o caminho em direção à equivalência de gêneros parece ser bastante longo e repleto de desconstruções a serem realizadas.

No entanto, julgamos importante destacar que nem toda a experiência foi de estereótipos e visões reducionistas. Salientamos como maior descoberta o comportamento de Milena ao entender que meninas podem jogar bola e desconstruir padrões estereotipados. Ela mesma em alguns momentos provou essa desconstrução ao se destacar como líder, ao brincar com os meninos, e ao não se importar com a aparência como acredita que todas as meninas se importam, inclusive contrariando a opinião da mãe. Milena nos mostrou que existe possibilidade de transgressão de qualquer que seja o discurso (mesmo o que é proveniente de um processo de internalização como o de sua mãe), e que essa transgressão pode sim ser realizada pelas crianças. 
Outro aspecto que se mostrou positivo e ao mesmo tempo ambíguo foi um conjunto de experiências com Martim. A criança que demonstrou comportamentos reducionistas e que falou que quem "usa rosa é gay", é a mesma criança que, nos primeiros dias de observação participante criou um personagem masculino de massinha de modelar vestido de rosa. Ao ser questionado sobre quem era o personagem, ele respondeu que era "o dono de um restaurante que também estava construindo". Nesse momento, ele e todas as crianças que ali estavam agiram com a grande naturalidade sobre o homem de massinha estar usando a cor rosa. Em outro episódio, Martim advertiu os colegas sobre o bullying, considerando que é errado isolar uma criança só por que ela é diferente. O comportamento de Martim nestas situações foi bastante transgressor, gerando um contraponto com suas manifestações expressas para a turma. Podemos supor que ele internalizou certas situações e outras não, pois ele se manteve na defensiva durante o debate em sala de aula, porém na hora de agir naturalmente, ele vestiu o dono do restaurante de massinha de modelar rosa. Essas manifestações androcêntricas podem ser reproduções advindas de um processo de internalização familiar dos ideais do pai, a pessoa com quem ele afirmou possuir maior identificação. Não almejamos tornar isso uma constatação, mas evidenciar que mesmo nos comportamentos mais extremos existem atravessamentos e possibilidade de ideais mais igualitários.

Em conclusão final dos apontamentos aqui realizados, acreditamos que o consumo atua na configuração das concepções de gênero principalmente através dos significados incutidos nos brinquedos e na apropriação coletiva desses, que segue uma lógica atrelada aos estereótipos sexuais. Destacamos também o papel do consumo midiático na relação familiar, que apontou uma forte interferência nos modelos-padrão de família e um possível enfraquecimento dos processos de socialização e internalização. Além do consumo, a escola se mostrou um espaço de determinação de estereótipos, reforçando visões um tanto limitadas acerca dos comportamentos esperados para crianças. De modo geral, as relações de classe permearam este estudo em alguns momentos e se mostraram atuantes no que diz respeito tanto ao consumo e quanto às estratégias disciplinares. Ainda, destacamos que apesar de existir uma forte tendência estereotipada e legitimada pelo consumo e pela escola, também existem comportamentos e visões disruptivas que nos incitaram a continuar buscando e acreditando na equivalência de gêneros. 


\section{CONSIDERAÇÕES FINAIS}

Para avançar no que aqui tomamos como primeiro passo, acreditamos que pensar uma educação em termos de gênero para as crianças é uma forma de prevenir comportamentos intolerantes às diferenças no que diz respeito ao gênero e a sexualidade. Consideramos que esses pressupostos educacionais precisam caminhar em conjunto com uma reformulação das práticas de consumo de um modo geral.

Como sugestão para futuros estudos, consideramos a educomunicação uma proposta que pode intervir nesse processo de forma muito produtiva, na medida em que pressupõe o fortalecimento da comunicação nos espaços educativos a fim de "desenvolver o espírito crítico dos usuários dos meios massivos, usar adequadamente os recursos da informação nas práticas educativas, e ampliar capacidade de expressão das pessoas” (SOARES, 2003, p. 1).

Apontamos como grande desafio neste processo o reconhecimento de o quanto ainda é difícil oferecer às crianças uma educação de qualidade no que diz respeito à própria alfabetização e outros princípios básicos, tornando o estudo do gênero um cenário ainda distante. Por isso, acreditamos que para além de pensar a educação de gênero nas escolas, é preciso também preocupar-se com uma educação de qualidade em todos os sentidos. Apostamos nas pequenas iniciativas como grandes passos para o alcance de uma sociedade com maior equivalência entre gêneros, acreditando na democratização da comunicação e nas potencialidades dos meios de comunicação para a promoção de um diálogo mais abrangente e diversificado.

\section{REFERÊNCIAS}

BERGER, P.; LUCKMANN, T. A construção social da realidade. Rio de janeiro: Ed. Vozes, 2011.

BOURDIEU, P. A dominação masculina. Tradução: Maria Helena Kühner. Rio de Janeiro: Bertrand Brasil, 2012.

GARCÍA CANCLINI, N. Consumidores e cidadãos: conflitos multiculturais da globalização. Rio de Janeiro: Editora UFRJ, 1995.

DELEUZE, G.; GUATTARI, F. Mil platôs - capitalismo e esquizofrenia. Tradução: Aurélio Guerra Neto e Célia Pinto Costa. Rio de Janeiro: Ed. 34, 1995. 
DUARTE, J. Entrevista em profundidade. In: DUARTE, J. (Org.); BARROS, A. (Org.) Métodos e Técnicas de pesquisa em Comunicação. 2. ed. São Paulo: Atlas, 2009, p. 62-82.

KASTRUP, V. O funcionamento da atenção no trabalho do cartógrafo. Psicologia \& Sociedade, Rio de Janeiro, n 19 (1), jan/abr. 2007. Disponível em:

<http://www.scielo.br/pdf/psoc/v19n1/a03v19n1.pdf>. Acesso em: 11 ago 2016.

LOURO, G. L. Gênero, sexualidade e educação: uma perspectiva pós-estruturalista. 10 ed. Petrópolis, RJ: Vozes, 2008.

MARTÍN-BARBERO, J. Dos meios às mediações: comunicação, cultura e hegemonia. Tradução: Ronald Polito e Sérgio Alcides. Rio de Janeiro: Editora UFRJ, 1997.

PERUZZO, C. M. K. Observação participante e pesquisa-ação. In: DUARTE, J. (Org.); BARROS, A. (Org.) Métodos e Técnicas de pesquisa em Comunicação. 2. ed. São Paulo: Atlas, 2009, p. 125-143.

SCOTT, J. Gênero: uma categoria útil para análise histórica. Tradução: Christine Rufino Dabat, Maria Betânia Ávila. New York, Columbia University Press. 1989. Disponível em: $<$ http://disciplinas.stoa.usp.br/pluginfile.php/185058/mod_resource/content/2/G\%C3\%AAneroJoan\%20Scott.pdf>. Acesso em: 11 ago 2016.

SETTON, M. G. J. Família, escola e mídia: um campo com novas configurações. Educação e Pesquisa, São Paulo, v.28, n.1, p. 107-116, jan./jun. 2002. Disponível em: <http://www.scielo.br/pdf/ep/v28n1/11659.pdf>. Acesso em: 11 ago 2016.

VYGOTSKY, L. S. A formação social da mente: o desenvolvimento dos processos psicológicos superiores. Michael Cole (org.). São Paulo: Martins Fontes, 1991.

\section{Original recebido em: 16 de agosto de 2016}

Aceito para publicação em: 05 de abril de 2017

\section{Juliana Petermann}

Doutora em Ciências da Comunicação pela Universidade do Vale do Rio dos Sinos. Professora no curso de Publicidade e Propaganda e no Programa de Pós-Graduação em Comunicação na Universidade Federal de Santa Maria.

Desirè̀ Ribas Fumagalli

Mestra em Comunicação pela Universidade Federal de Santa Maria. Graduada em Comunicação Social - Publicidade e Propaganda pela Universidade Federal de Santa Maria.

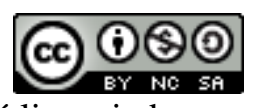

Esta obra está licenciado com uma Licença 


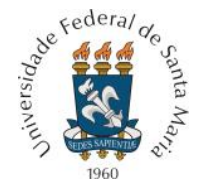

PROGRAMA DE PÓS-GRADUAÇÃO EM COMUNICAÇÃO DA UNIVERSIDADE FEDERAL DE SANTA MARIA

Creative Commons Atribuição-NãoComercial-CompartilhaIgual 4.0 Internacional 